\title{
FINANCIAL STABILITY AND INCOME GROWTH IN EMERGING MARKETS
}

\author{
Bashir T. Mande*, Afees A Salisu*,, Adeola N. Jimoh", Fola Dosumu*, \\ Girei H. Adamu* \\ * Research Policy and International Relations Department, Nigeria Deposit Insurance \\ Corporation (NDIC), Abuja \\ ** Corresponding author. Centre for Econometric \& Allied Research, University of Ibadan. \\ Email: adebare1@yahoo.com
}

\begin{abstract}
In this paper, we examine the extent to which financial stability matters for income growth in emerging markets. Using dynamic panel estimation techniques, we explore both the stock market and banking sector dimensions of the financial system to show that both stock market volatility and non-performing loans are detrimental to income growth in these markets. We, however, find the magnitude of the impact to be relatively more pronounced when the underlying source of instability in the financial system is stock market volatility. Overall, we find the impact of financial stability on income growth to be more statistically relevant when measured using the individual indicators of financial instability as compared to their composite indicator.
\end{abstract}

Keywords: Financial stability; Emerging markets; Static and dynamic panels.

JEL Classifications: C33; E01; E44; O11.

\author{
Article history: \\ Received : January 9, 2020 \\ Revised : : March 22, 2020 \\ Accepted : July 05, 2020 \\ Available online : August 21, 2020 \\ https://doi.org/10.21098/bemp.v23i2.1247
}




\section{INTRODUCTION}

Unlike the advanced economies, which have already reached a steady state of development and have low marginal investment returns and factor productivity, emerging market economies have high growth potential for investment returns and factor productivity (Romer, 2011). This macroeconomic postulation, which is based on the law of diminishing marginal productivity, has a significant implication for return maximizing portfolio investors. The literature on international portfolio diversification provides ample evidence supporting the potential gains from diversification via emerging markets' financial assets (see, for example, Bergin and Pyun, 2015; Frugier, 2016; Kumar, 2011; Oloko, 2018; Pätäri et al., 2019). Despite the potential portfolio investment gains in emerging market economies, the role of a stable and resilient macroeconomic environment in attracting foreign investors cannot be overemphasized (Al Nasser, 2010; Alguacil et al., 2011). Since financial markets provide funds for the real sector, the pertinent question in the case of emerging market economies is: how does financial stability affect income growth? In this paper, we provide answers to this question. Understanding the impact of financial instability on income growth has become more apparent considering the recent rise in global uncertainty primarily driven by the coronavirus outbreak. ${ }^{1}$

The literature argues in favour of a nexus between economic growth and financial stability by asserting that a stable and well-developed financial system is critical in enhancing efficiency and promoting investment. This is possible through funding potentially profitable business opportunities, mobilising savings, monitoring the performance of managers, enabling trading, hedging, diversification of risk, and facilitating the exchange of goods and services (see Aghion et al., 2005; Madichie et al., 2014; Meierrieks, 2014; Phan et al., 2020). These functions ensure an efficient allocation of resources, rapid accumulation of physical and human capital, and a faster technological progress, which, in turn, promote economic growth (see Khan, et al., 2005; Creane et al., 2006; Aghion and Howitt, 2009; Ho and Iyke, 2017). Thus, financial instability will likely impede economic growth as the core function of a financial system, including financial intermediation role, is constrained when the system becomes unstable (see Chiarell and Di Guilmi, 2011; Cesa-Bianchi \& Rebucci, 2017; Lhuissier, 2017). Notably, banking failure, liquidity trap, and volatility of asset prices are some of the key features of an unstable financial system (Alsamara et al., 2019).

Financial stability is one of the important goals of macroeconomic management and it is a functional responsibility of central banks and other public authorities (European Central Bank, 2016). Several studies examine the relationship between financial stability and economic growth and report mixed conclusions. Earlier studies that suggest a negative relationship between financial stability and economic growth include Ma (2019) and Fouejieu et al. (2019). Both studies, however, observe the relationship from the central banks' policy making perspective. For instance, Ma (2019) examines the effect of optimal macro prudential policy in a

\footnotetext{
1 A growing number of studies emphasize the rising level of global market uncertainty as a result of the coronavirus outbreak (see, for example, Devpura and Narayan, 2020; Gil-Alana and Monge, 2020; Haroon and Rizvi, 2020; Huang and Zheng, 2020; Iyke, 2020a,b; Mishra et al., 2020; Narayan, 2020; Phan and Narayan, 2020; Prabheesh et al., 2020; Salisu and Adediran, 2020; Salisu and and Akanni, 2020; Vidya and Prabheesh, 2020).
} 
small open economy model and finds a trade-off between economic growth and financial stability. Similarly, Fouejieu et al. (2019) demonstrate that a central bank attempting to "lean against the wind" may face trade-offs between inflation/ output stability and financial stability.

In contrast, other studies suggest a positive relationship between financial stability and income growth. These studies include Pholphirul (2008), Creel et al. (2015), Aboura and van Roye (2017), and Sotiropoulou et al. (2019). According to Aboura and van Roye (2017), episodes of high financial stress are associated with significantly low economic activity, whereas episodes of low financial stress are insignificantly associated with economic activity. Besides, Creel et al. (2015) and Sotiropoulou et al. (2019) find that financial instability has a negative effect on economic growth, and Pholphirul (2008) finds that financial sector stability helps stabilize economic growth.

This study contributes to the literature in the following distinct ways. First, it focuses on emerging market economies. The consideration of these economies is important because they are target investment destinations for portfolio investors seeking to maximize returns (see Oloko, 2018; Pätäri et al. 2019). In addition, earlier studies considered a single country or group of developed or developing economies. For example, Creel et al. (2015) and Sotiropoulou et al. (2019) focus on European economies while Batuo et al. (2018) consider African countries. On single country studies, Aboura and van Roye (2017) consider France and Cheang (2004) and Pholphirul (2008) consider Thailand and Macao, respectively.

Secondly, our study explores both the stock market and banking sector dimensions of the financial system by using both stock market volatility and nonperforming loans as measures of financial stability. Unlike previous studies, these measures allow us to test the hypothesis that banking failure is more detrimental to income growth than the volatility in asset prices. The intuition here is that banks remain "special", as instability in the banking sector has a greater capacity to generate systematic contagion than stock market volatility. This is another contribution of our study to the literature.

The remainder of the paper is structured as follows. Section II briefly reviews existing studies. Section III explains the data and offers some preliminary analysis. Section IV outlines the model specification and estimation procedures, while section V presents the empirical findings. Section VI concludes the paper.

\section{LITERATURE REVIEW}

As pointed out in Section 1, the majority of the extant studies predominantly focus on the relationship between gross domestic product (GDP) growth and financial development (see, for example, Zhu et al., 2020; Mollaahmetoglu and Akcair, 2019; Sotiropoulou et al., 2019; Botev, 2019; Chu, 2019; Batuo et al., 2018; Ho and Iyke, 2018; Ranjbar and Rassekh, 2017; Dilek et al., 2017; Creel et al., 2015; Samargandi et al., 2014; Adu et al., 2013; Khan et al., 2005; Ibrahim and Alagidede, 2018; Madsen et al., 2018; Ono, 2017; Yang and Yi, 2008; Khan et al., 2001). Furthermore, studies that have considered the impact of financial stability on economic growth mostly focus on developed countries (see, for example, Alsamara et al., 2019; Duprey et al., 2017; Aboura and van Roye, 2017, Creel et al., 2015; Klemkosky, 2013). 


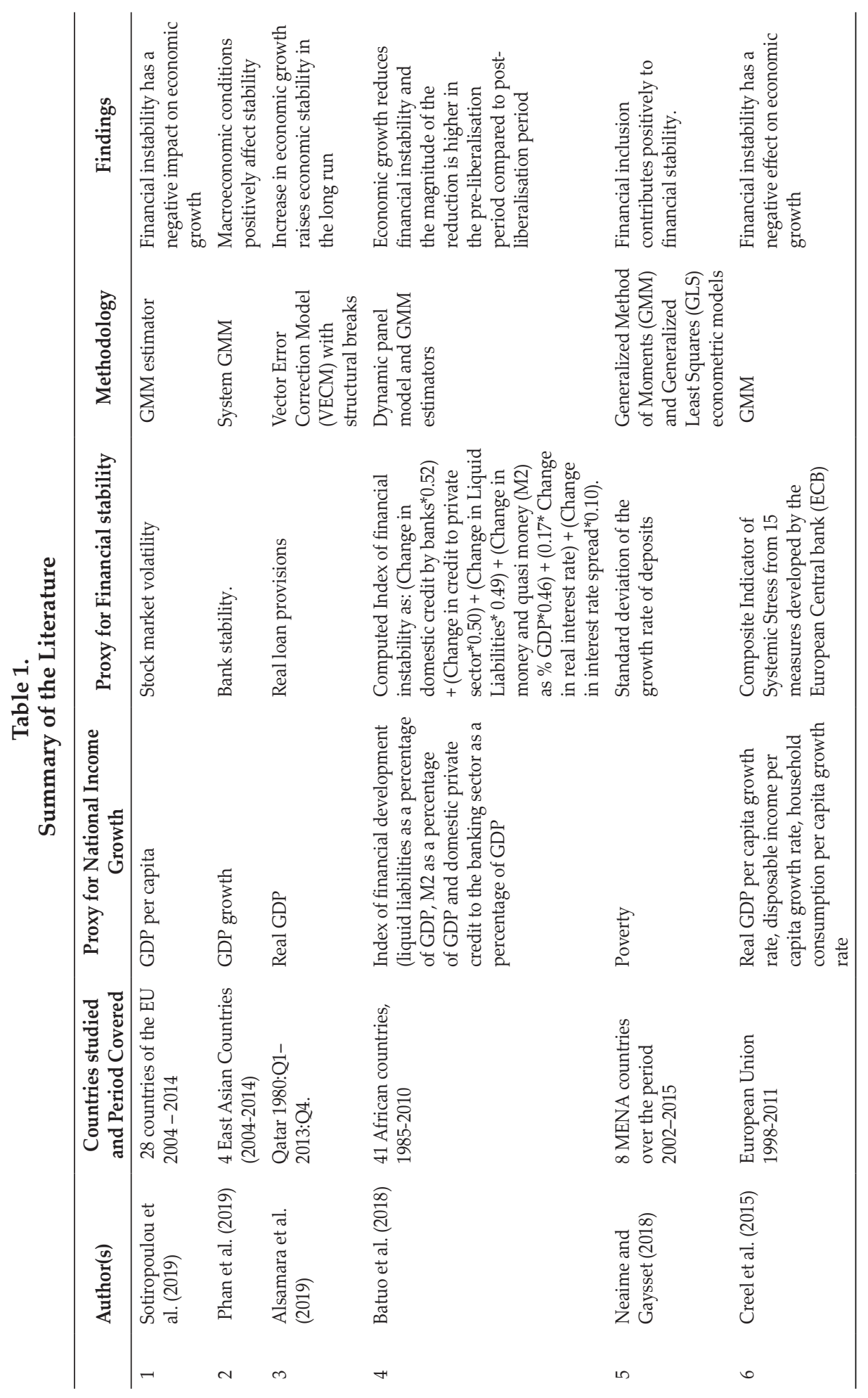




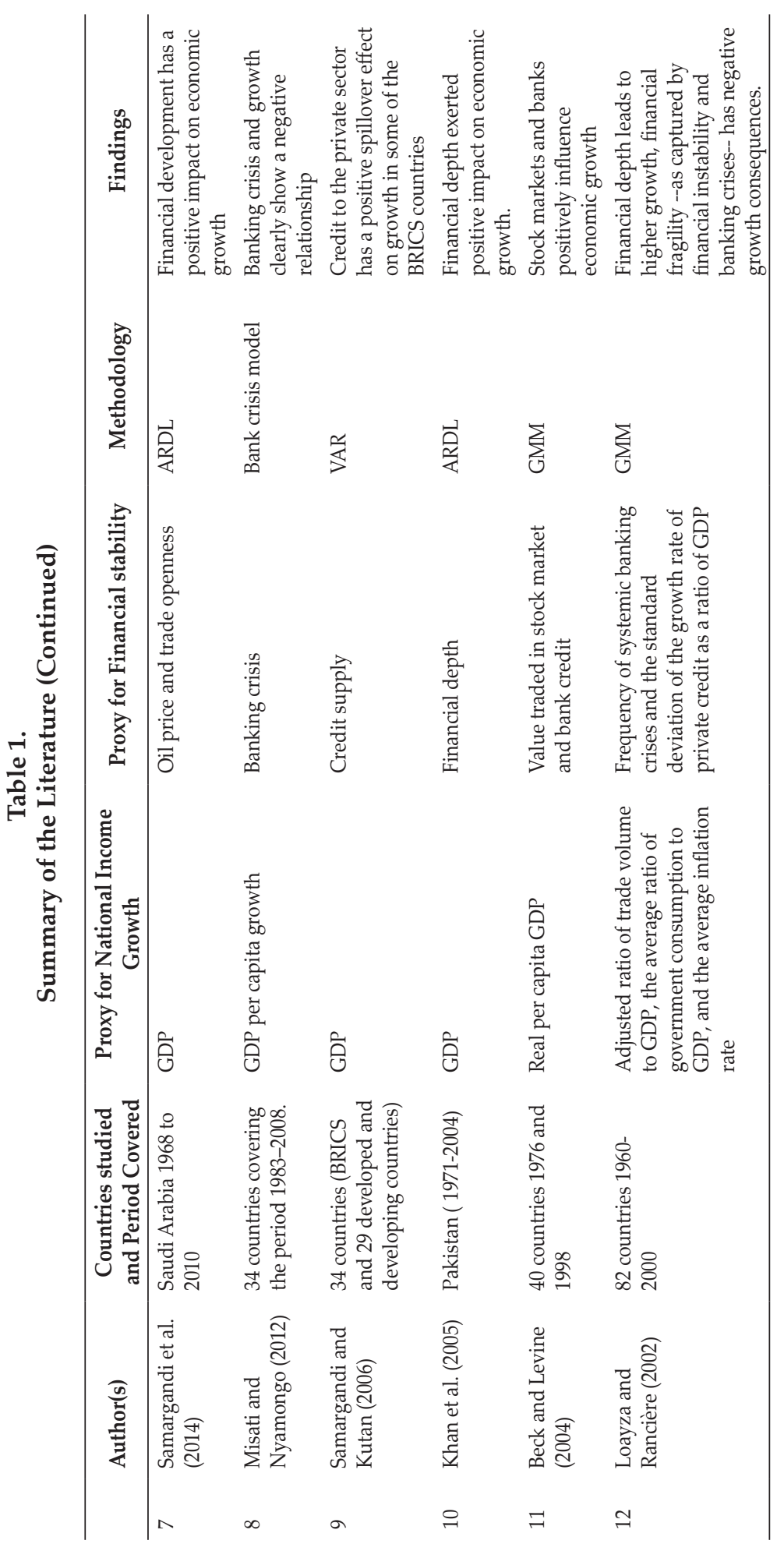


Several of these studies conclude that financial stability (instability) negatively impacts economic growth, which is consistent with the work of Minsky (1992), demonstrating that financial instability affects the organization of a financial sector by increasing financial costs and resource misallocation, and, in turn, reducing economic growth. ${ }^{2}$

In contrast, Cheang (2004) shows that financial stability has no direct contribution to economic growth, while Sotiropoulou et al. (2019), Batuo et al. (2018), Jeanneney and Kpodar (2011), Creane et al. (2006), and Beck and Levine (2004) find a positive impact of financial stability on economic growth. Notable among the few extant studies that consider emerging and developing countries are Phan et al. (2019), Ahamed and Mallick (2018), Neaime and Gaysset (2018), and Loayza and Raciere (2002). Thus, in addition to the relative dearth of empirical literature in the case of emerging market economies, a cursory look at Table 1 suggests that the extant literature is far from conclusive regarding the direction of the impact of financial stability (instability) on economic growth.

\section{DATA AND PRELIMINARY RESULTS}

The perspectives and definitions of financial stability are diverse and controversial, especially around its linkage to economic performance (see Creel et al., 2015). In an attempt to capture the key segments of the financial systems, namely, stock market and the banking sector, particularly the relative impacts of their stability (instability) on income growth, we used two financial stability indicators, namely the stock market volatility (SMV) index and non-performing loans (NPL). Starting with the latter, which captures the banking segment of the financial system, its viability as a measure of financial stability from the banking sector perspective is often attributed to its relevance as a warning signal of systematic banking insolvency (see Alsamara et al., 2019; Cihak and Schaeck, 2010). Financial stability (instability) from the perspective of the stock market activity is measured as the 360-day standard deviation of the return on the national stock market index. To test the robustness of our estimates, we complement these individual indicators of financial stability with a composite indicator, the Z-score. The Z-score, according to Creel et al. (2015), combines the banking and stock market dimensions of financial stability (instability). To put it differently, the Z-score is a composite of (i) bank profitability, (ii) capital ratio, and (iii) return volatility.

To effectively compare our findings with the extant literature, we further consider a broad number of conventional growth determinants, namely, population growth $(P O P)$ as an indicator of labor force growth, gross fixed capital formation as a ratio of GDP and credit to private sector (CPS) as a ratio of GDP (both used to capture investment in physical capital $(P K)$ ), gross enrolment ratio in secondary education (i.e. secondary school enrolment to gross enrolment in all the three levels of education) as a measure of human capital (HK), government consumption $(G C)$ as a ratio of GDP to accommodate the government sector in the growth regressions, inflation rate (INFL) to reflect the macroeconomic environment, and trade openness (TOP) measured as the sum of exports and

2 See also Guichard and Turner (2008) and Pholphirul (2008) for similar explanations. 
imports scaled by GDP to capture the importance of international factor flows in influencing economic activities (see Iyke, 2018; Ho and Iyke, 2020; Juhro et al., 2020). We used the logarithm of the first difference of per capita GDP as our measure of income growth. Table 2 shows the basic statistical summary of each of these variables, while Table 3 shows the pairwise correlation between the variables. The data are annual series, covering the period between 1996 and 2018, Data are sourced from the World Bank's online database. Based on the Morgan Stanley Capital International Emerging Market Index (MSCI Index), only 26 developing countries qualify as emerging markets, ${ }^{3}$ but 23 of these countries are included in our sample due to data availability.

Table 2.

\section{Summary Statistics}

This table presents the statistical summary of the variables under consideration including their mean, standard deviation (Std. Dev.), and maximum and minimum values of each variable. Variables are defined as GDP is per capita GDP in US dollars, $P O P$ is population growth, $P K$ is physical capital, $H K$ is human capital, GC is government consumption, CPS is credit to private sector, INFL is inflation rate, TOP is trade openness, SMV is the stock market volatility, and NPL is non-performing loan.

\begin{tabular}{|c|c|c|c|c|}
\hline & Mean & Std. Dev. & Min. & Max. \\
\hline \multicolumn{5}{|c|}{ Growth regression conventional determinants } \\
\hline GDP & 9170.40 & 6617.89 & 711.93 & 30054.89 \\
\hline PO & 1.37 & 1.57 & -1.04 & 15.18 \\
\hline$P K$ & 23.04 & 6.33 & 11.07 & 45.69 \\
\hline HK & 85.38 & 19.63 & 9.29 & 130.44 \\
\hline GC & 14.92 & 4.37 & 5.69 & 30.00 \\
\hline CPS & 52.90 & 40.31 & 0.12 & 164.18 \\
\hline INFL & 6.62 & 9.78 & -1.74 & 85.75 \\
\hline TOP & 68.11 & 39.88 & 15.64 & 220.41 \\
\hline \multicolumn{5}{|c|}{ Financial stability indictors } \\
\hline SMV & 24.39 & 12.43 & -0.81 & 107.31 \\
\hline$N P L$ & 8.00 & 9.07 & 0.28 & 80.00 \\
\hline Z-score & 11.69 & 7.20 & 0.02 & 96.68 \\
\hline
\end{tabular}

3 Argentina, Brazil, Chile, China, Colombia, the Czech Republic, Egypt, Greece, Hungary, India, Indonesia, Korea, Malaysia, Mexico, Qatar, Pakistan, Peru, the Philippines, Poland, Russia, South Africa, South Korea, Taiwan, Thailand, Turkey, and the United Arab Emirates. 
Table 3.

\section{Correlation Coefficients}

This table reports unconditional correlations. All variables are as defined in Table 2 . Finally, ${ }^{*}(* *)^{* * *}$ denote statistical significance at the $10 \%(5 \%) 1 \%$ levels.

\begin{tabular}{|c|c|c|c|c|c|c|c|c|c|c|c|}
\hline & GDP & POP & $P K$ & HK & $G C$ & CPS & INFL & TOP & $V L I$ & $N P L$ & Z-Score \\
\hline GDP & 1 & & & & & & & & & & \\
\hline POP & -0.04 & 1 & & & & & & & & & \\
\hline$P K$ & $0.39^{* * *}$ & 0.01 & 1 & & & & & & & & \\
\hline$H K$ & -0.05 & -0.06 & 0.06 & 1 & & & & & & & \\
\hline GC & $-0.20^{* * *}$ & $-0.08^{*}$ & $-0.12^{* *}$ & $0.52^{* * *}$ & 1 & & & & & & \\
\hline CPS & -0.01 & -0.07 & $0.30^{* * *}$ & $0.20^{* * *}$ & $0.13^{* *}$ & 1 & & & & & \\
\hline INFL & $-0.12^{* *}$ & $0.25^{* *}$ & $-0.13^{* *}$ & $-0.15^{* *}$ & $-0.15^{* *}$ & $-0.27^{* *}$ & 1 & & & & \\
\hline TOP & 0.01 & $-0.09^{*}$ & $0.16^{* * *}$ & $0.17^{* * *}$ & $0.17^{* * *}$ & $0.30^{* * *}$ & $-0.17^{* * *}$ & 1 & & & \\
\hline$S M V$ & $-0.19^{* *}$ & $0.13^{* * *}$ & $-0.10^{* *}$ & -0.05 & 0.03 & $-0.21^{* *}$ & $0.46^{* * *}$ & $-0.15^{* * *}$ & 1 & & \\
\hline$N P L$ & $-0.21^{* *}$ & $-0.12^{* *}$ & $-0.18^{* *}$ & $-0.36^{* *}$ & $-0.10^{* *}$ & 0.00 & $0.11^{* *}$ & 0.02 & $0.26^{* * *}$ & 1 & \\
\hline Z-Score & 0.07 & 0.02 & 0.05 & 0.01 & -0.05 & $0.10^{* *}$ & $-0.09^{* *}$ & -0.05 & $-0.11^{* *}$ & $-0.17^{* * *}$ & 1 \\
\hline
\end{tabular}

\section{MODEL SPECIFICATION AND ESTIMATION APPROACH}

Although, the objective of this study is to determine the extent to which financial stability (instability) matters for income growth in emerging market economies, following the standard approach in the literature (see for example, Botev et al., 2019; Creel et al., 2015; Samargandi et al., 2014), we commence our model specification with the conventional growth regression:

$$
y_{i t}=\alpha+\mu_{i}+x_{i, t}^{\prime} \beta+\varepsilon_{i, t}
$$

where $y_{i t}$ denotes income growth and is measured as the logarithm of the first difference of GDP per capita, while $x$ is a $k \times 1$ vector of income growth determinants, namely, POP, PK, HK, GC, CPS, INFL, and TOP. The subscripts $i$ and $t$ represent cross-sectional and time dimensions, while the parameters $\alpha$ and $\mu$ represent the constant term and the country-specific fixed effects, respectively.

To capture the effects of financial stability in the income growth regression, Equation (1) is further extended as follows:

$$
y_{i t}=\alpha+\mu_{i}+x_{i, t}^{\prime} \beta+\lambda z_{i, t}+\varepsilon_{i, t}
$$

where $z$ represents financial stability (instability), which is captured via both the stock market and banking sector segments of the financial system.

The income growth regressions in Equations (1) and (2) can be estimated via any of the standard panel model estimators, such as the pooled ordinary least squares estimator (POLS), fixed and random effects estimators. However, the POLS is regarded to be highly restrictive, given the heterogeneity consequence of its assumption of common intercept and slope coefficients for all cross-sections (see Baltagi, 2008). The fixed effects estimator assumes common slopes but variant country-specific intercepts and, therefore, tends to suffer from the loss of degrees of freedom (see Baltagi, 2008). In contrast to the fixed effects estimator, the random 
effects estimator is regarded as less problematic in terms of degrees of freedom since it assumes common intercepts (see Baltagi, 2008). This notwithstanding, the random effects assumption of no time variability is considered to be unrealistic as it implies that the error at any period is uncorrelated with the past, present, and future errors (see Arellano, 2003; Loayza and Ranciere, 2002).

Essentially, none of the aforementioned static approaches has the potential to capture the dynamic nature of the data, as they can only deal with structural heterogeneity, particularly in the form of random or fixed effects, while imposing a homogenous slope coefficient across countries, even though there may be substantial variations between them (see Samargandi et al., 2014). Besides, the relationship between financial stability and income growth may not be static as expressed in Equation (2). Rather, it is dynamic as income growth is explained by its lagged values, among other determinants (see Samargandi et al., 2014; Xue, 2020, among others). Hence, following Beck and Levine (2004) and Creel et al. (2015), we rewrite Equations (1) and (2), respectively, as:

$$
\begin{aligned}
& y_{i t}=\alpha+\mu_{i}+\delta y_{i, t-1}+x_{i, t}^{\prime} \beta+\varepsilon_{i, t} \\
& y_{i t}=\alpha+\mu_{i}+\delta y_{i, t-1}+x_{i, t}^{\prime} \beta+\lambda z_{i, t}+\varepsilon_{i, t}
\end{aligned}
$$

where $y_{i t-1}$ is the one-period lag of income growth and $\delta$ is the autocorrelation coefficient, while the other variables remain as previously defined. Following Arellano and Bond (1991) approach, the dynamic panel model in Equations (3) and (4) are estimable via the difference Generalized Method of Moments (GMM) estimator. However, to circumvent the potential bias associated with the use of the difference GMM estimator (see Alonso-Borrego and Arellano, 1999), we complement this approach with the alternative approach proposed by Arellano and Bover (1995) and Blundell and Bond (1998), namely, the system GMM. This notwithstanding, the system GMM is not without its own shortcomings, particularly since the number of instruments is likely to increase exponentially with the number of time periods leading to finite sample bias. To this end, both approaches will be implemented via a collapsed instrument matrix.

\section{EMPIRICAL FINDINGS}

\section{A. The Baseline Results}

Consistent with the standard practice in the literature (see, for example, Creel et al., 2015; Beck and Levine, 2004), we estimate the growth regression in Equation (3) and report the results in Table 4. We find the coefficients on PK, GC, and CPS to be statistically significant in explaining income growth in emerging market economies. When compared to credit to the private sector, the magnitude of the impact of GC and HK on income growth appears to be relatively more pronounced. More so, the sign or the direction of the relationship is as expected for $H K$ and GC but opposite for CPS. That is, while we expected credit to the private sector to promote economic growth, we find it reduces growth-CPS has a negative coefficient-which is consistent/inconsistent with Sotiropoulou et al. (2019) and Creel et al. (2015). This can be attributed to poor and inefficient credit allocation to 
projects that are not beneficial for economic activity and do not improve economic growth. We find that HK, INFL and TOP exert no significant impacts on income growth, which is consistent with Cree et al. (2015). To validate the assumption of no serial correlation in the error terms, we explore the standard specification tests in the literature. The $\mathrm{AR}(1)$ and $\mathrm{AR}(2)$ statistics suggest that the error terms are not serially correlated. In addition, the Hansen J-test results show that the instruments are valid.

Table 4.

\section{Dynamic Panel Estimation-Growth Regression}

This table reports the dynamic panel estimation -growth regression using the one-step and the two-step difference and system GMM estimators. The bottom of the table reports the $p$-values of standard specification tests. Robust (Windmeijer) standard errors are in brackets while the statistical significance is defined as ${ }^{* * *} \mathrm{p}<0.01,{ }^{* *} \mathrm{p}<0.05$, \& * $\mathrm{p}<0.1$. All variables in column 1 are as defined in Table 2 .

\begin{tabular}{lcccc}
\hline & $\mathbf{( 1 )}$ & $\mathbf{( 2 )}$ & $\mathbf{( 3 )}$ & $\mathbf{( 4 )}$ \\
\cline { 2 - 5 } & Diff-GMM(1) & Diff-GMM(2) & Sys-GMM(1) & Sys-GMM(2) \\
\hline GDP(-1) & $-0.1770^{* * *}$ & 0.2300 & $0.2110^{* * * *}$ & $0.1900^{* *}$ \\
POP & $(0.0741)$ & $(0.5370)$ & $(0.0615)$ & $(0.0908)$ \\
& $-0.0060^{* * *}$ & -0.0082 & -0.0010 & -0.0009 \\
PK & $(0.0015)$ & $(0.0064)$ & $(0.0011)$ & $(0.0015)$ \\
& $0.0045^{* *}$ & 0.0094 & $0.0016^{* * *}$ & $0.0014^{* *}$ \\
HK & $(0.0021)$ & $(0.0078)$ & $(0.0005)$ & $(0.0006)$ \\
& 0.0002 & 0.0218 & $7.61 \mathrm{e}-05$ & $9.21 \mathrm{e}-05$ \\
\hline GC & $(0.0002)$ & $(0.0265)$ & $(0.0001)$ & $(0.0001)$ \\
\hline \multirow{2}{*}{ CPS } & $-0.0135^{* * *}$ & -0.0090 & $-0.0018^{* * *}$ & $-0.0017^{* *}$ \\
& $(0.0046)$ & $(0.0075)$ & $(0.0005)$ & $(0.0007)$ \\
INFL & $-0.0015^{* * *}$ & -0.0129 & $-0.0001^{* *}$ & $-9.36 \mathrm{e}-05$ \\
& $(0.0003)$ & $(0.0147)$ & $(6.57 \mathrm{e}-05)$ & $(0.0001)$ \\
TOP & $-0.0012^{* *}$ & 0.0010 & -0.0006 & -0.0006 \\
& $(0.0006)$ & $(0.0029)$ & $(0.0005)$ & $(0.0010)$ \\
\hline Constant & 0.0004 & -0.0015 & $3.15 \mathrm{e}-05$ & $2.12 \mathrm{e}-05$ \\
& $(0.0003)$ & $(0.0030)$ & $(4.46 \mathrm{e}-05)$ & $(7.85 \mathrm{e}-05)$ \\
\hline No. of Obs. & & & 0.0129 & 0.0146 \\
No. of Group & & & $(0.0090)$ & $(0.0123)$ \\
AR(1) & 460 & 483 & 483 \\
Hansen J-test $p$-value & 23 & 23 & 23 & 23 \\
\hline & 0.09 & 0.45 & 0.00 & 0.01 \\
& 0.02 & 0.40 & 0.50 & 0.51 \\
& & -03 & 0.53 & 0.61 \\
\hline
\end{tabular}




\section{B. Financial Stability and Income Growth}

We now turn to the focal point of the study, which is to examine the impact of financial stability on income growth. Financial stability (instability) is captured via both the stock market and banking sector segments of the financial system but estimated independently so as to distinguish the dynamics of income growth attributable to stability (instability) in the stock market from those attributable to banking sector stability (instability). In Table 5, we consider the impact of stock market stability (instability) on income growth. To do this, we extend the income growth regression to include the $S M V$ index - a measure of the stock market dimension of financial stability. First, the introduction of financial stability in the model does not affect the overall fit of the model or the impacts of the conventional indicators on income growth. That is, the impact of GC and PSC on income growth remain negative, while the impact of $P K$ on growth remains positive, after introducing financial stability to the model. Financial instability, as measured by $S M V$, has a negative and significant impact on income growth, consistent with Sotiropoulou et al. (2019), Creel et al. (2015), and Kim et al. (2014). This means that despite the widespread assertion of a positive relationship between finance and growth, instability in the stock market may prompt investors to seek more riskless investments, which would, consequently, harm economic growth.

Turning to the banking sector dimension of financial stability (instability), we find the coefficient on NPL, as reported in Table 6, is negative and statistically significant in the growth regressions. This suggests that financial instability, measured in terms of non-performing loans, has a negative impact on income growth. This could be due to the ineffectiveness in the credit allocation process, which reduces profitability, increases financial costs, binds the bank capital, reduces credit supply to the private sector, and, in turn, reduces economic growth. On the whole, we find both the stock market and banking sector dimensions of financial stability (instability) are capable of hurting income growth. However, a cursory look at Tables 5 and 6 indicates that the magnitude of the impact of financial instability is higher when measured by $S M V$ than when measured by NPL.

Table 5.

\section{Dynamic Panel Estimation of Income Growth-Financial Stability Relation}

This table reports the dynamic panel estimation of income growth-financial stability nexus using the one-step and the two-step difference and system GMM estimators. The bottom of the table reports the $p$-values of standard specification tests. Robust (Windmeijer) standard errors are in brackets while the statistical significance is defined as ${ }^{* * *} \mathrm{p}<0.01,{ }^{* *}$ $\mathrm{p}<0.05, \&{ }^{*} \mathrm{p}<0.1$. All variables in column 1 are as defined in Table 2 .

\begin{tabular}{lcccc}
\hline & $\mathbf{( 1 )}$ & $\mathbf{( 2 )}$ & $\mathbf{( 3 )}$ & $\mathbf{( 4 )}$ \\
\cline { 2 - 5 } & Diff-GMM(1) & Diff-GMM(2) & Sys-GMM(1) & Sys-GMM(2) \\
\hline \multirow{2}{*}{ GDP(-1) } & -0.0930 & -0.1260 & $0.2150^{* * *}$ & $0.2340^{*}$ \\
& $(0.0758)$ & $(0.0785)$ & $(0.0664)$ & $(0.1340)$ \\
POP & $-0.0041^{* * *}$ & $-0.0043^{* * *}$ & -0.00102 & -0.0013 \\
& $(0.0012)$ & $(0.0013)$ & $(0.0008)$ & $(0.0018)$ \\
PK & $0.0041^{* *}$ & $0.0046^{* *}$ & $0.0017^{* * *}$ & $0.0015^{* * *}$ \\
& $(0.0019)$ & $(0.0020)$ & $(0.0003)$ & $(0.0005)$ \\
\hline
\end{tabular}


Table 5.

Dynamic Panel Estimation of Income Growth-Financial Stability Relation (Continued)

\begin{tabular}{lcccc}
\hline & $\mathbf{( 1 )}$ & $\mathbf{( 2 )}$ & $\mathbf{( 3 )}$ & $\mathbf{( 4 )}$ \\
\cline { 2 - 5 } & Diff-GMM(1) & Diff-GMM(2) & Sys-GMM(1) & Sys-GMM(2) \\
\hline$H K$ & -0.0002 & -0.0001 & $-5.65 \mathrm{e}-05$ & $1.38 \mathrm{e}-05$ \\
GC & $(0.0002)$ & $(0.0002)$ & $(9.71 \mathrm{e}-05)$ & $(0.0001)$ \\
& $-0.0088^{* *}$ & $-0.0101^{* * *}$ & $-0.0010^{* *}$ & -0.0012 \\
CPS & $(0.0039)$ & $(0.0032)$ & $(0.0004)$ & $(0.0007)$ \\
& $-0.0014^{* * *}$ & $-0.0014^{* * *}$ & $-0.0001^{*}$ & $-8.67 \mathrm{e}-05$ \\
INFL & $(0.0003)$ & $(0.0003)$ & $(5.37 \mathrm{e}-05)$ & $(8.40 \mathrm{e}-05)$ \\
& -0.0004 & -0.0007 & -0.0003 & -0.0003 \\
TOP & $(0.0006)$ & $(0.0006)$ & $(0.0004)$ & $(0.0010)$ \\
& $-7.01 \mathrm{e}-05$ & -0.0001 & $1.35 \mathrm{e}-05$ & $1.51 \mathrm{e}-05$ \\
SMV & $(0.0003)$ & $(0.0003)$ & $(3.25 \mathrm{e}-05)$ & $(6.20 \mathrm{e}-05)$ \\
& $-0.0016^{* * *}$ & $-0.0016^{* * *}$ & $-0.0021^{* * *}$ & $-0.0018^{* * *}$ \\
Constant & $(0.0003)$ & $(0.0003)$ & $(0.0002)$ & $(0.0004)$ \\
\hline No. of Obs. & & & 0.0070 & 0.0084 \\
No. of Group & 460 & & $(0.0090)$ & $(0.0121)$ \\
AR(1) & 23 & 460 & 483 & 483 \\
AR(2) & 0.04 & 23 & 23 & 23 \\
Hansen J-test $p$-value & 0.16 & 0.06 & 0.00 & 0.00 \\
\hline
\end{tabular}

\section{Robustness Check}

We subject our finding to a robustness check by complementing the individual indicators of financial stability (instability) with a composite indicator, the Z-score. The Z-score combines the banking and stock market dimensions of financial stability (instability). While the finding appears to be robust, particularly in terms of the direction of the impact of financial stability (instability) on income growth, the coefficient on Z-score, as reported in Table 7, is insignificant. This implies that a better way to gauge the impact of financial instability on income growth is via the individual indicators. 
Table 6.

\section{Dynamic Panel Estimation of Income Growth-Financial Stability (NPL) Nexus}

This table reports the dynamic panel estimation of income growth-financial stability nexus using the one-step and two step difference and system GMM estimators. The bottom of the table reports the $p$-values of standard specification tests. Robust (Windmeijer) standard errors are in brackets while the statistical significance is defined as ${ }^{* * *} \mathrm{p}<0.01,{ }^{* * *}$ $\mathrm{p}<0.05, \&{ }^{*} \mathrm{p}<0.1$. All variables in column 1 are as defined in Table 2 .

\begin{tabular}{|c|c|c|c|c|}
\hline & $(1)$ & $(2)$ & (3) & (4) \\
\hline & Diff-GMM(1) & Diff-GMM(2) & Sys-GMM(1) & Sys-GMM(2) \\
\hline \multirow{2}{*}{$G D P / c_{-1}$} & $-0.1760^{* *}$ & -0.1750 & $0.1880^{* * *}$ & $0.2441^{* * *}$ \\
\hline & $(0.0724)$ & $(0.1190)$ & $(0.0624)$ & $(0.0928)$ \\
\hline \multirow[t]{2}{*}{$L A B$} & $-0.0059^{* * *}$ & $-0.0061^{* *}$ & -0.0011 & $-8.40 \mathrm{e}-05$ \\
\hline & $(0.0018)$ & $(0.0031)$ & $(0.0012)$ & $(0.0014)$ \\
\hline \multirow[t]{2}{*}{$P K$} & $0.0042^{* *}$ & 0.0031 & $0.0016^{* * *}$ & $0.0014^{* * *}$ \\
\hline & $(0.0019)$ & $(0.0026)$ & $(0.0004)$ & $(0.0004)$ \\
\hline \multirow[t]{2}{*}{$H K$} & 0.0002 & 0.0002 & 0.0001 & 0.0001 \\
\hline & $(0.0002)$ & $(0.0004)$ & $(0.0001)$ & $(0.0001)$ \\
\hline \multirow[t]{2}{*}{$G C$} & $-0.0128^{* * *}$ & $-0.0165^{* *}$ & $-0.0014^{* *}$ & $-0.0015^{* *}$ \\
\hline & $(0.0045)$ & $(0.0083)$ & $(0.0005)$ & $(0.0007)$ \\
\hline \multirow[t]{2}{*}{ CPS } & $-0.0015^{* * *}$ & $-0.0013^{* * *}$ & $-0.0001^{* *}$ & -0.0001 \\
\hline & $(0.0003)$ & $(0.0004)$ & (5.56e-05) & $(7.27 \mathrm{e}-05)$ \\
\hline \multirow[t]{2}{*}{ INFL } & $-0.0011^{*}$ & -0.0013 & -0.0006 & -0.0009 \\
\hline & $(0.0006)$ & $(0.0009)$ & $(0.0006)$ & $(0.0007)$ \\
\hline \multirow[t]{2}{*}{ TOP } & 0.0003 & 0.0005 & $-1.51 \mathrm{e}-05$ & $-1.35 e-05$ \\
\hline & $(0.0003)$ & $(0.0005)$ & $(4.29 \mathrm{e}-05)$ & (6.41e-05) \\
\hline \multirow[t]{2}{*}{ NPL } & $-0.0015^{* *}$ & -0.0009 & $-0.0040^{* *}$ & -0.0016 \\
\hline & $(0.0006)$ & $(0.0007)$ & $(0.0019)$ & $(0.0020)$ \\
\hline \multirow[t]{2}{*}{ Constant } & & & 0.0064 & 0.0099 \\
\hline & & & $(0.0098)$ & $(0.0115)$ \\
\hline No. of Obs. & 460 & 460 & 483 & 483 \\
\hline No. of Group & 23 & 23 & 23 & 23 \\
\hline $\mathrm{AR}(1)$ & 0.09 & 0.02 & 0.00 & 0.03 \\
\hline $\mathrm{AR}(2)$ & 0.20 & 0.16 & 0.20 & 0.21 \\
\hline Hansen J-test $p$-value & 0.12 & 0.10 & 0.50 & 0.50 \\
\hline
\end{tabular}


Table 7.

Dynamic Panel Estimation of Income Growth-Financial Stability (Z -score) Relation

This table reports the dynamic panel estimation of income growth -financial stability nexus using the one-step and the two-step difference and system GMM estimators. The bottom of the table reports the $p$-values of standard specification tests. Robust (Windmeijer) standard errors are in brackets while the statistical significance is defined as ${ }^{* * *} \mathrm{p}<0.01,{ }^{* *} \mathrm{p}<0.05, \&^{*} \mathrm{p}<0.1$. All variables in column 1 are as defined in Table 2 .

\begin{tabular}{lcccc}
\hline & $\mathbf{( 1 )}$ & $\mathbf{( 2 )}$ & $\mathbf{( 3 )}$ & $\mathbf{( 4 )}$ \\
\cline { 2 - 5 } & Diff-GMM(1) & Diff-GMM(2) & Sys-GMM(1) & Sys-GMM(2) \\
\hline GDP(-1) & $-0.1760^{* *}$ & $-0.2000^{*}$ & $0.2110^{* * *}$ & $0.1930^{* *}$ \\
POP & $(0.0737)$ & $(0.112)$ & $(0.0612)$ & $(0.0917)$ \\
& $-0.0060^{* * *}$ & $-0.0054^{* * *}$ & -0.0010 & -0.0009 \\
PK & $(0.0015)$ & $(0.0020)$ & $(0.0011)$ & $(0.0015)$ \\
& $0.0045^{* *}$ & 0.0043 & $0.0016^{* * *}$ & $0.0014^{* *}$ \\
HK & $(0.0021)$ & $(0.0030)$ & $(0.0005)$ & $(0.0006)$ \\
& 0.0002 & 0.0003 & $7.53 \mathrm{e}-05$ & $9.04 \mathrm{e}-05$ \\
GC & $(0.0002)$ & $(0.0003)$ & $(9.97 \mathrm{e}-05)$ & $(0.0001)$ \\
& $-0.0135^{* * *}$ & $-0.0175^{* *}$ & $-0.0018^{* * *}$ & $-0.0017^{* *}$ \\
CPS & $(0.0047)$ & $(0.0087)$ & $(0.0005)$ & $(0.0007)$ \\
& $-0.0015^{* * *}$ & $-0.0014^{* * *}$ & $-0.0001^{* *}$ & $-8.98 \mathrm{e}-05$ \\
INFL & $(0.0003)$ & $(0.0005)$ & $(6.56 \mathrm{e}-05)$ & $(9.85 \mathrm{e}-05)$ \\
& $-0.0012^{* *}$ & -0.0014 & -0.0006 & -0.0006 \\
TOP & $(0.0006)$ & $(0.0009)$ & $(0.0005)$ & $(0.0010)$ \\
& 0.0003 & 0.0003 & $3.10 \mathrm{e}-05$ & $2.08 \mathrm{e}-05$ \\
Z-score & $(0.0003)$ & $(0.0005)$ & $(4.44 \mathrm{e}-05)$ & $(7.76 \mathrm{e}-05)$ \\
& $-7.77 \mathrm{e}-05$ & -0.0001 & -0.0001 & $-5.35 \mathrm{e}-05$ \\
Constant & $(0.0001)$ & $(0.0002)$ & $(0.0002)$ & $(0.0003)$ \\
\hline No. of Obs. & & & 0.0130 & 0.0148 \\
No. of Group & & & $(0.0090)$ & $(0.0121)$ \\
AR(1) & $0.05(2)$ & 460 & 483 & 483 \\
Hansen J-test $p$-value & 0.03 & 23 & 23 \\
\hline & 0.03 & 0.47 & 0.00 & 0.01 \\
& & 0.35 & 0.80 & 0.52 \\
& & & & 0.81 \\
\hline
\end{tabular}

\section{CONCLUSION}

The literature has established the role of finance in engendering income growth in emerging markets via the efficient allocation of resources, promotion of profitable investment activities, diversification of risks, and facilitation of exchange of goods and services. However, the role of financial stability (instability) in income growth is still relatively less understood, particularly in emerging markets. To offer robust insights on the extent to which financial stability matters for income growth in emerging markets, we explore both the stock market and banking sector dimensions 
of the financial system. We show that: (i) financial instability resulting from both stock market volatility and non-performing loans is detrimental to income growth in the 23 emerging market economies we study; (ii) the magnitude of the negative impact of financial instability on income growth appears to be relatively more pronounced via the stock market volatility channel; and (iii) in terms of statistical significance, the individual indicators of financial instability better explain income growth than the composite indicator.

\section{REFERENCES}

Aboura, S., \& van Roye, B. (2017). Financial Stress and Economic Dynamics: the Case of France. International Economics, 149, 57-73.

Adu, G., Marbuah, G. and Mensah, J.T. (2013). Financial Development and Economic Growth in Ghana: Does the Measure of Financial Development Matter. Review of Development Finance, 3, 192-203.

Aghion, P., and Howitt, P. (2009). The Economics of Growth. Cambridge, Massachusetts: The MIT Press.

Aghion, P., Howitt, P., and Mayer-Foulkes, D. (2005). The Effect of Financial Development on Convergence: Theory and Evidence. Quarterly Journal of Economics, 120, 323-351.

Ahamed, M.M. and Mallick, S.K. (2018). Is Financial Inclusion Good for Bank Stability: International Evidence? Journal of Economic Behavior E Organization, 403-427.

Al Nasser, O. M. (2010). How Does Foreign Direct Investment Affect Economic Growth? The Role of Local Conditions. Latin American Business Review, 11, 111139.

Alguacil, M., Cuadros, A. and Orts, V. (2011). Inward FDI and Growth: The Role of Macroeconomic and Institutional Environment. Journal of Policy Modeling, 33, 481-496.

Alonso-Borrego, C. and Arellano, M. (1999). Symmetrically Normalized Instrumental Variable Estimation Using Panel Data. Journal of Business and Economic Statistics, 17, 36-49.

Alsamara, M., Mrabet, Z., Jarallah, S. and Barkat, K. (2019). The Switching Impact of Financial Stability and Economic Growth in Qatar: Evidence from an OilRich Country. The Quarterly Review of Economics and Finance, 73, 205-216.

Arellano, M. (2003). Panel Data Econometrics: Advanced Texts in Econometrics. Oxford University Press, UK.

Arellano, M. and Bond, S. (1991). Some Tests of Specification for Panel Data: Monte Carlo Evidence and an Application to Employment Equations. Review of Economic Studies, 58, 277-297.

Arellano, M. and Bover, O. (1995). Another Look at the Instrumental Variable Estimation of Error-Components Models. Journal of Econometrics, 68, 29-51.

Baltagi, B.H. (2008) Econometric Analysis of Panel Data. John Wiley \& Sons Ltd., Chichester.

Batuo, M., Mlambob, K. and Asongu, S. (2018). Linkages between Financial Development, Financial Instability, Financial Liberalisation and Economic Growth in Africa. Research in International Business and Finance, 45, 168-179. 
Beck, T. and Levine, R. (2004). Stock Markets, Banks, and Growth: Panel Evidence. Journal of Banking E Finance, 28, 423-442.

Bergin, P.R., Pyun, J.H. (2015). International Portfolio Diversification and Multilateral Effects of Correlations. Journal of International Money and Finance 1-66.

Blundell, R. and Bond, S. (1998). Initial Conditions and Moment Restrictions in Dynamic Panel Data Models. Journal of Econometrics, 87, 115-143.

Botev, J., Egert, B. and Jawadi, F. (2019). The Nonlinear Relationship between Economic Growth and Financial Development: Evidence from Developing, Emerging and Advanced Economies. International Economics, 160, 3-13.

Cesa-Bianchi, A. \& Rebucci, A. (2017). Does Easing Monetary Policy Increase Financial Instability? Journal of Financial Stability, 30, 111-125.

Cheang, N. (2004). Financial Stability and Economic Growth of Macao. AMCM Quarterly Bulletin, 11, 67-87.

Chu, L.L. (2019). Financial Structure and Economic Growth Nexus Revisited. Borsal Istanbul Review, DOI: https://doi.org/10.1016/j.bir.2019.08.003

Chiarell, C. \& Di Guilmi, C. (2011). The Financial Instability Hypothesis: A Stochastic Microfoundation Framework. Journal of Economic Dynamics and Control, 35, 1151-1171.

Cihak, M. and Schaeck, K. (2010). Competition, efficiency, and soundness in banking: An industrial organization perspective. Discussion Paper, No. 68S, Tilburg University, Center for Economic Research.

Creane, S., Goyal, R., Mobarak, M.A. \& Sab, R. (2006). Measuring Financial Development in the Middle East and North Africa: A New Database. IMF Staff Papers, 53, 479-511.

Creel, J., Hubert, P. and Labondance, F. (2015). Financial Stability and Economic Performance. Economic Modelling, 48, 25-40.

Devpura, N., and Narayan, P.K., (2020) Hourly Oil Price Volatility: The Role of COVID-19, Energy Research Letters, 1(2), 13683. https://doi. org/10.46557/001c.13683.

Dilek, D., Serdar, I.M. and Yetkiner, H. (2017). Financial Development and Economic Growth: Some Theory and More Evidence. Journal of Policy Modeling, 39, 290-306.

Duprey, T., Klaus, B., and Peltonen, T. (2017). Dating Systemic Financial Stress Episodes in the EU Countries. Journal of Financial Stability, 32, 30-56.

European Central Bank (2016). Spotlight on Financial Stability. Retrieved from https://www.ecb.europa.eu/explainers/tell-me-more/html/financial_stability. en.html.

Frugier, A. (2016). Returns, Volatility and Investor Sentiment: Evidence from European Stock Markets. Research in International Business and Finance, 38, 4555.

Fouejieu, A. Popescu, A. and Villieu, P. (2019). Trade-Offs between Macroeconomic and Financial Stability Objectives. Economic Modelling, 81, 621-639.

Gil-Alana, L. A., \& Monge, M. (2020). Crude oil prices and COVID-19: Persistence of the shock. Energy Research Letters, 1(1), 13200. https://doi. org/10.46557/001c.13201c.132 
Guichard, S., and Turner D. (2008). Quantifying the Effect of Financial Conditions on US Activity. OECD Economics Department Working Papers, No 635.

Haroon, O., and Rizvi, S.A.R. (2020). Flatten the Curve and Stock Market Liquidity - an Inquiry into Emerging Economies. Emerging Markets Finance and Trade, 56, 2151-2161; https://doi.org/10.1080/1540496X.2020.1784716.

Ho, S. Y., and Iyke, B. N. (2017). Determinants of Stock Market Development: A Review of the Literature. Studies in Economics and Finance, 34, 143-164.

Ho, S. Y., and Iyke, B. N. (2018). Finance-Growth-Poverty Nexus: A Re-Assessment of the Trickle-Down Hypothesis in China. Economic Change and Restructuring, 51, 221-247.

Ho, S. Y., and Iyke, B. N. (2020). The Determinants of Economic Growth in Ghana: New Empirical Evidence. Global Business Review, 21, 626-644.

Ibrahim, M. and Alagidede, P. (2018). Nonlinearities in Financial DevelopmentEconomic Growth Nexus: Evidence from Sub-Saharan Africa. Research in International Business and Finance, 46, 95-10.

Huang, W., \& Zheng, Y., (2020) COVID-19: Structural changes in the relationship between investor sentiment and crude oil futures price, Energy Research Letters, 1(2), 13685. https://doi.org/10.46557/001c.13685

Iyke, B. N. (2018). The Real Effect of Currency Misalignment on Productivity Growth: Evidence from Middle-Income Economies. Empirical Economics, 55, 1637-1659.

Iyke, B.N., (2020a) COVID-19: The Reaction of US Oil and Gas Producers to the Pandemic, Energy Research Letters, 1(2), 13912. https://doi. org/10.46557/001c.13912

Iyke, B.N., (2020b). The Disease Outbreak Channel Of Exchange Rate Return Predictability: Evidence from COVID-19, Emerging Markets Finance and Trade, 56, 2277-2297; https://doi.org/10.1080/1540496X.2020.1784718.

Jeanneney, S.G. and Kpodar, K. (2011). Financial Development, Financial Instability and Poverty. IMF Working Paper, No. 08/62.

Juhro, S. M., Narayan, P. K., Iyke, B. N., and Trisnanto, B. (2020). Is there a role for Islamic finance and R\&D in endogenous growth models in the case of Indonesia? Pacific-Basin Finance Journal, 101297. https://doi.org/10.1016/j. pacfin.2020.101297.

Khan, M.A., Qayyum, A. and Sheikh, S.A. (2005). Financial Development and Economic Growth: The case of Pakistan. Pakistan Development Review, 819-837.

Kim, T.Y., Shin, J., Kim, Y. and Lee, J.D. (2014). The Relationship among Stock Markets, Banks, Economic Growth, and Industry Development. In Economic Growth, 279292, Springer Berlin Heidelberg.

Klemkosky, R.C. (2013). Financial System Fragility. Business Horizons, 56, 675-683.

Kumar, S. S. S. (2011). Are Emerging Markets Relevant for Portfolio Diversification? Review of Market Integration, 3, 103-119.

Lhuissier, S. (2017). Financial Intermediaries' Instability and Euro Area Macroeconomic Dynamics. European Economic Review, 98, 49-72.

Loayza, N. and Ranciere, R. (2002). Financial Development, Financial Fragility and Growth. Venice: Center for Economic Studies \& Ifo Institute for Economic Research, Paper No. 684, 1-35. 
Ma, C. (2019). Financial Stability, Growth and Macroprudential Policy. Journal of International Economics, https://doi.org/10.1016/j.jinteco.2019.103259.

Madsen, J. B., Islam, M. R. and Doucouliagos, H. (2018). Inequality, Financial Development and Economic Growth in the OECD, 1870-2011. European Economic Review, 101, 605-624.

Madichie, C., Maduka, A., Oguanobi, C. and Ekesiobi, C. (2014). Financial Development and Economic Growth in Nigeria: a Reconsideration of Empirical Evidence. Journal of Economics and Sustainable Development, 5, 199-208.

Meierrieks, D. (2014). Financial Development and Innovation: Is There Evidence of a Schumpeterian Finance-Innovation Nexus? Annals of Economics and Finance, 15, 343-363.

Minsky, H.P. (1992). The Financial Instability Hypothesis. The Jerome Levy Economics Institute Working Paper No. 74.

Misati, R.N. and Nyamongo, E.M. (2012). Financial liberalization, financial fragility and economic growth in Sub-Saharan. Journal of Financial Stability, 150-160.

Mishra, A.K., Rath, B.N., and Dash, A.K., (2020) Does the Indian Financial Market Nosedive Because of the COVID-19 Outbreak, in Comparison to after Demonetisation and the GST? Emerging Markets Finance and Trade, 56(10), 21622180; https://doi.org/10/1080/1540496X.2020.1785425.

Mollaahmetoglu, E. and Akcair, B.Y. (2019). The Missing-link between Financial Development and Economic Growth: Financial Innovation. Procedia Computer Science, 158, 696-704.

Narayan, P. K. 2020. Oil Price News and COVID-19-Is There any connection? Energy Research Letters, 13176. https://doi.org/10.46557/001c.13176

Neaime, S. and Gaysset, I. (2018). Financial Inclusion and Stability in MENA: Evidence from Poverty and Inequality. Finance Research Letters, 24, 230-237.

Oloko, T. F. (2018). Portfolio Diversification between Developed and Developing Stock Markets: The Case of US and UK Investors in Nigeria. Research in International Business and Finance 45, 219-232.

Pätäri, E., Ahmed, S., John, E. and Karell, V. (2019). The Changing Role of Emerging and Frontier Markets in Global Portfolio Diversification. Cogent Economics $\mathcal{E}$ Finance, 7, 1-23.

Phan, D.H.B., and Narayan, P.K. (2020). Country Responses and the Reaction of the Stock Market to COVID-19-A Preliminary Exposition, Emerging Markets Finance and Trade, 56, 2138-2150; https://doi.org/10.1080/1540496X.2020.1784719

Phan, D. H. B., Iyke, B. N., Sharma, S. S., and Affandi, Y. (2020). Economic Policy Uncertainty and Financial Stability-Is There a Relation?. Economic Modelling. https://doi.org/10.1016/j.econmod.2020.02.042.

Phan, H.T., Anwar, S. and Alexander, R.W. (2019). Competition, Efficiency and Stability: an Empirical Study of East Asian Commercial Banks. North American Journal of Economics and Finance, DOI: https://doi.org/10.1016/j. najef.2019.100990.

Pholphirul, P. (2008). Financial Instability, Banking Crisis, and Growth Volatility: an Investigation of Bi-Directional Relationship. International Journal of Business and Management, 3, 97-110. 
Prabheesh, K.P., Padhan, R., and Garg, B. (2020). COVID-19 and the Oil PriceStock Market Nexus: Evidence from Net Oil-Importing Countries, Energy Research Letters, 1(2), 13745. https://doi.org/10.46557/001c.13745

Ranjbar, O. and Rassekh, F. (2017). The Impact of Financial Development on Income Convergence: an Application of Two Exogenous Growth Models. International Review of Economics and Finance, 50, 65-74.

Romer, D. (2011). Advanced Macroeconomics. McGraw-Hill Education; 4th edition.

Salisu, A.A., and Akanni, L.O. (2020). Constructing a Global Fear Index for COVID-19 Pandemic, Emerging Markets Finance and Trade, 56, 2213-2230; https://doi.org/10.1080/1540496X.2020.1785424.

Salisu, A., \& Adediran, I. (2020). Uncertainty Due to Infectious Diseases and Energy Market Volatility. Energy Research Letters, 1(2), 14185. https://doi. org/10.46557/001c.14185

Samargandi, N. and Kutan, A.M. (2006). Private Credit Spillovers and Economic Growth: Evidence from BRICS Countries. Journal of International Financial Markets, Institutions \& Money, 123-142.

Samargandi, N., Fidrmuc, J., and Ghosh, S. (2014). Financial Development and Economic Growth in an Oil-Rich Economy: The Case of Saudi Arabia. Economic Modelling, 43, 267-278.

Sotiropoulou, T., Giakoumatos, S.G. and Petropoulos, D.P. (2019). Financial Development, Financial Stability and Economic Growth in European Union: a Panel Data Approach. Advances in Management \& Applied Economics, 55-69.

Vidya, C. T., and Prabheesh, K.P. (2020) Implications of Covid-19 Pandemic on The Global Trade Networks, Emerging Markets Finance and Trade, 56, 2408-2421 https://doi.org/10.1080/1540496X.2020.1785426.

Xue, W. (2020). Financial Sector Development and Growth Volatility: An International Study. International Review of Economics \& Finance, https://doi. org/10.1016/j.iref.2020.06.025.

Yang, Y.Y. and Yi, M.H. (2008). Does Financial Development Cause Economic Growth? Implication for Policy in Korea. Journal of Policy Modeling, 30, 827-840.

Zhu, X., Asimakopoulos, S. and Kim, J. (2020). Financial Development and Innovation-Led Growth: Is Too Much Finance Better? Journal of International Money and Finance, 100, 1-24. 
This page is intentionally left blank 